\title{
DOMESTIC FELINE CUTANEOUS LEISHMANIASIS IN THE MUNICIPALITY OF RIBAS DO RIO PARDO, MATO GROSSO DO SUL STATE, BRAZIL: A CASE REPORT
}

\author{
Souza AI (1), Nunes VLB (2), Borralho VM (1), Ishikawa EAY (3)
}

(1) Department of Veterinary Medicine, Center of Biological, Agrarian and Health Sciences, University for the Development of the State and the Pantanal Region, UNIDERP, Campo Grande, Mato Grosso do Sul State, Brazil; (2) Department of Pharmacy, Center of Biological, Agrarian and Health Sciences, University for the Development of the State and the Pantanal Region, UNIDERP, Campo Grande, Mato Grosso do Sul State, Brazil; (3) Tropical Medicine Unit, State University of Pará, Belém, Pará State, Brazil and Evandro Chagas Institute, Secretary of Health Vigilance, Ministry of Health, Ananindeua, Pará State, Brazil.

ABSTRACT: Cutaneous leishmaniases are anthropozoonoses that involve many species of Leishmania and a wide variety of wild mammalian hosts, thus presenting high importance to public health. This study reports the second case of feline leishmaniasis in Mato Grosso do Sul state, in which Leishmania (Leishmania) amazonensis was found in a domestic cat from Ribas do Rio Pardo. Clinical signs were similar to those observed in other diseases commonly diagnosed in cats, such as cryptococcosis and sporotrichosis. Cutaneous leishmaniasis should, therefore, be added to differential diagnoses by feline veterinary practitioners, and also adequate investigations should be carried out to verify the relevance of domestic cats as $L$. amazonensis reservoirs.

KEY WORDS: cutaneous leishmaniasis, Leishmania (Leishmania) amazonensis, domestic cat, Mato Grosso do Sul state.

CONFLICTS OF INTEREST: There is no conflict.

\section{CORRESPONDENCE TO:}

ALDA IZABEL DE SOUZA, Curso de Medicina Veterinária, Centro de Ciências Biológicas, Agrárias e da Saúde, Universidade para o Desenvolvimento do Estado e da Região do Pantanal, UNIDERP, Campo Grande, MS, 79037-280, Brasil. Phone: +55 673818 3024. Email: aldaizabel@hotmail.com. 


\section{INTRODUCTION}

Cutaneous leishmaniases are important diseases in relation to morbidity, especially in tropical areas throughout the world. Their etiological agents comprise several species of the genus Leishmania that determine different clinical aspects and present diversified epidemiology as well as heterogeneous distribution $(1,2)$.

Leishmaniases are considered anthropozoonoses of wild animals that may infect humans at zoonotic foci. The epidemiological profile of cutaneous leishmaniases in Brazil involves a broad range of domestic and wild hosts and several phlebotomine species (3-7).

The present study aimed to describe the second case of cutaneous leishmaniasis in the state of Mato Grosso do Sul (MS), attributed to L. (Leishmania) amazonensis, in a domestic feline from the municipality of Ribas do Rio Pardo.

\section{CASE REPORT}

An adult domestic feline, from Ribas do Rio Pardo (MS), was referred for clinical assistance at the Veterinary Hospital of UNIDERP, presenting ulcerated lesions in the muzzle and nodules on the borders of both ears.

The animal was submitted to physical examination, hematological assay and serum biochemical tests of urea, creatinine and alanine aminotransferase (ALT). Clinical exams revealed ulcerated and hemorrhagic lesions on the muzzle, which provoked constant sneezing and mild inspiratory dyspnea (Figure 1). Floating nodules of varied sizes were also found in the pinnae. Cat physical examination showed no alteration. Blood tests presented only a mild leukocytosis with neutrophilia while the results of serum biochemistry (urea, creatinine and ALT) were in compliance with normal values for this species.

Aspiration puncture in the nodules was performed for cytological evaluation. Smears were prepared and stained by the panoptic method. The aspirated material was also cultured in a McNeal, Novy and Nicole (NNN) medium with an aqueous phase containing brain-heart infusion (BHI) and subcutaneously inoculated into the upper limbs of two hamsters (Mesocricetus auratus).

The smear from the lesion aspirate presented a large quantity of extracellular and intracellular amastigotes in macrophages (Figure 2) while numerous promastigotes were observed in the culture, five days post-cultivation. The parasite was identified as Leishmania (Leishmania) amazonensis by indirect immunofluorescence reaction, 
Souza Al et al. Domestic feline cutaneous leishmaniasis in the municipality of Ribas do Rio Pardo, Mato Grosso do Sul, State, Brazil: A case report. J Venom Anim Toxins incl Trop Dis. 2009;15(2):361

employing monoclonal antibodies and the biotin-avidin system, according to Shaw et al. (2). About 15 days after the inoculation, experimental animals presented cutaneous lesions similar to those of the cat.
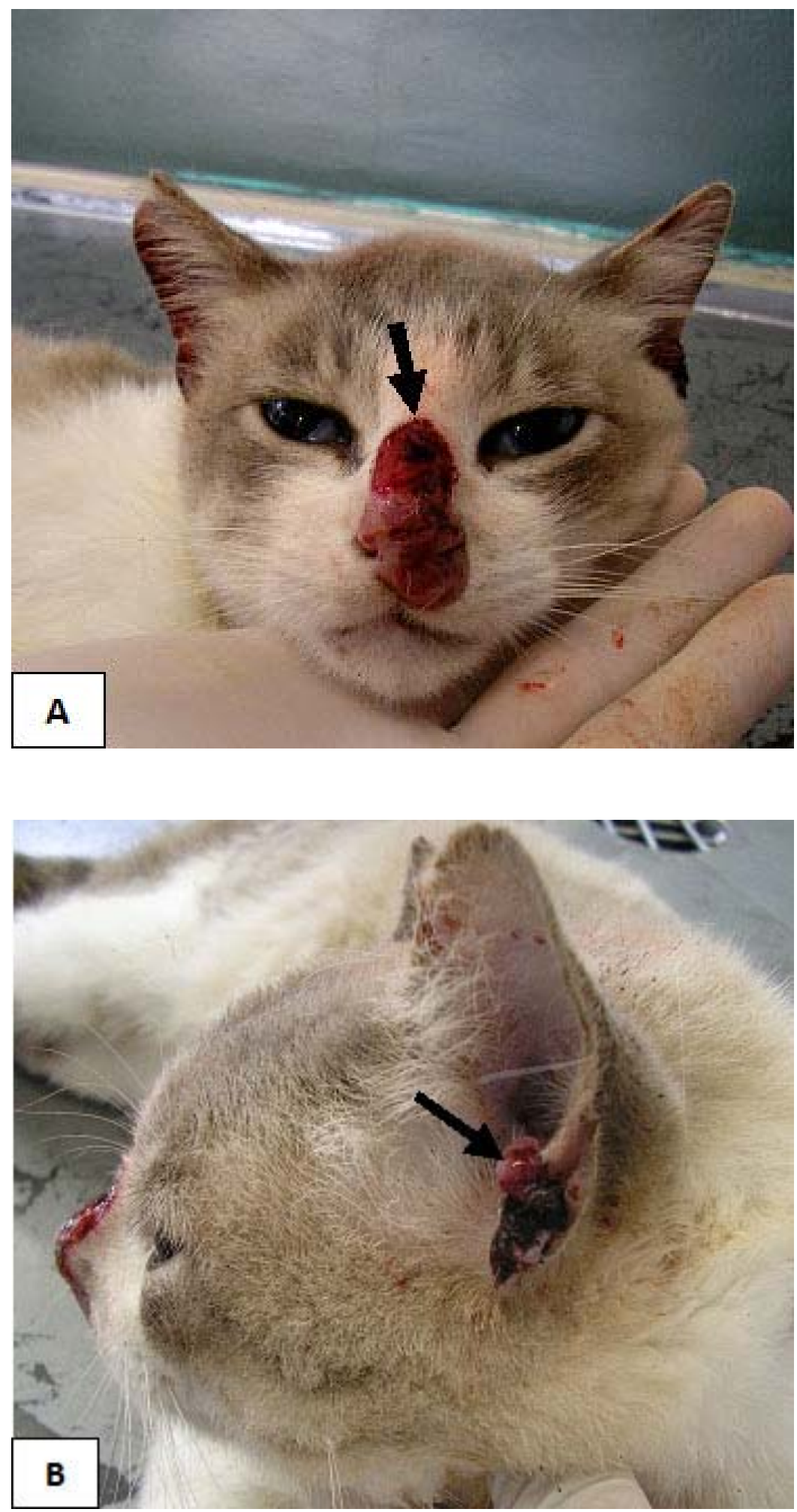

Figure 1. Cutaneous leishmaniasis in a feline infected with Leishmania (Leishmania) amazonensis; (A) ulcerated lesion on the nose and (B) nodules on the ear border. 


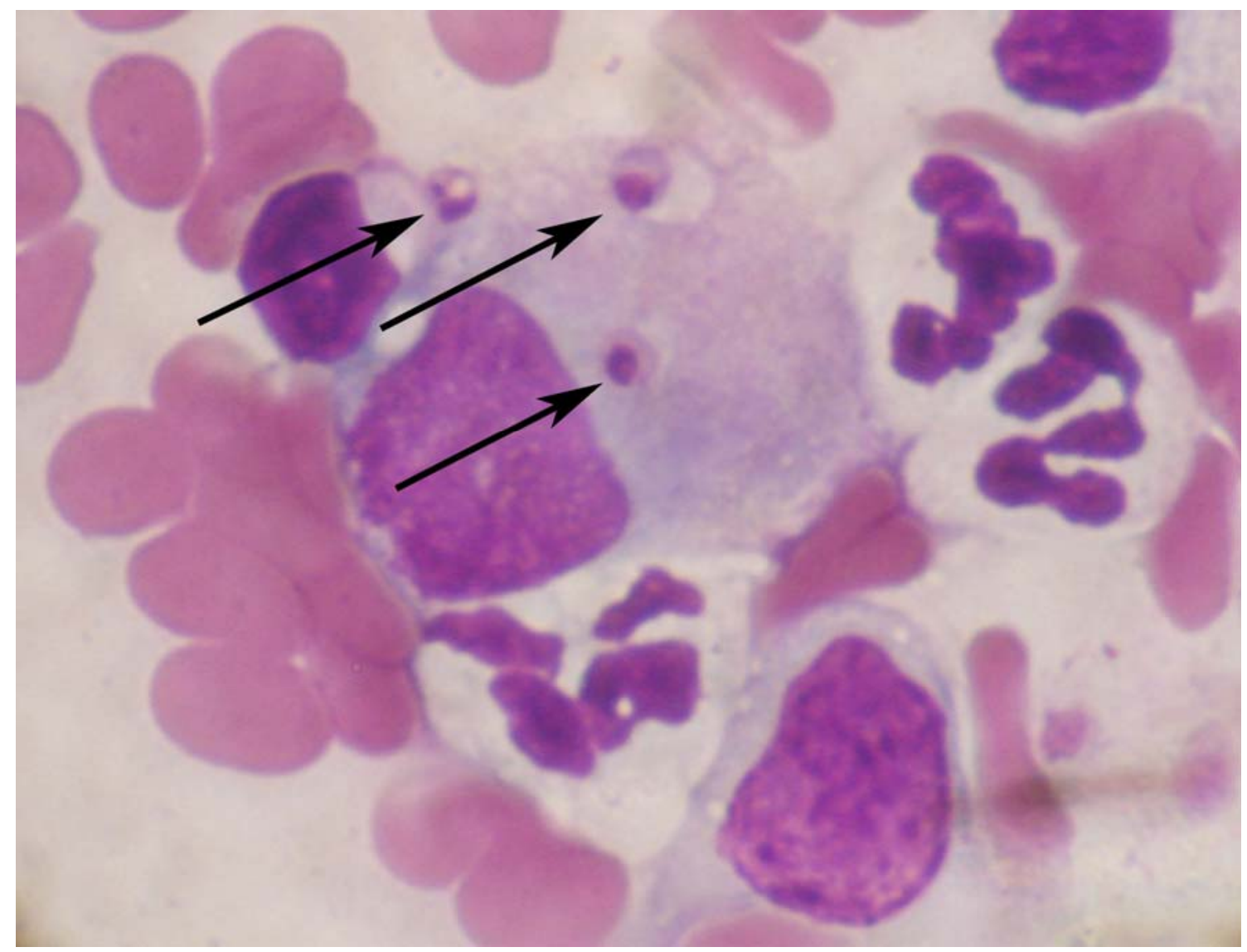

Figure 2. Extracellular and intracellular amastigotes found in smear from a lesion aspirate (arrows) from a feline infected with Leishmania (Leishmania) amazonensis.

\section{DISCUSSION}

Leishmania (L.) amazonensis is the etiological agent of anergic diffuse cutaneous leishmaniasis and is distributed broadly throughout Latin America including several regions of Brazil $(1,8,9)$.

In Mato Grosso do Sul, human cases of Leishmania (L.) amazonensis were reported in Bela Vista city, in the south of the Bodoquena mountain ridge; whereas cat infections were registered in Assentamento Guaicurus, on the western slope of the central portion of the mountain ridge, in the municipality of Bonito $(10,11)$. Its main vector, Bichromomyia flaviscutellata, a phlebotomine that usually does not affect humans, was found in Campo Grande and Bonito, respectively, the south and central areas of the Bodoquena mountain ridge (12-14).

Although several studies have reported domestic animals as American cutaneous leishmaniasis $(A C L)$ reservoirs, the literature indicates that feline cases are rare and 
sporadic (4, 7, 15-18). In Brazil, natural infection in domestic cats has been registered in Belo Horizonte, Rio de Janeiro and Campo Grande (19-22).

As already observed by the aforementioned authors, clinical signs of protozoan diseases in cats are unspecific and similar to other infections that affect these animals, especially sporotrichosis and cryptococcosis - fungal diseases manifested through nodules and cutaneous ulcers with frequent nose impairment $(23,24)$. It is noteworthy that the lesions observed in the present case were less severe than those reported in previous cases.

The occurrence, in Mato Grosso do Sul, of a second case of ACL in a cat - though in geographically distinct places - and its similarity to cutaneous manifestations caused by other pathogens reinforces the need to alert veterinarians to include this disease in the differential diagnosis of feline dermatopathy.

Additionally, it is important to note that, although cases reported in felines are scarce, the current situation of ACL reservoirs in Mato Grosso do Sul remains unknown. Moreover, the lawless occupation of land, very common in the state, with abrupt changes in the original vegetation and weather alterations are factors that force phlebotomine adaptation to urban areas and may, therefore, favor the disease transmission among domestic animals (24). Further studies are necessary to clarify the role of domestic cats, as well as of other animals, in the cycle of leishmanial transmission in this region.

\section{REFERENCES}

1. Basano SA, Camargo LMA. Leishmaniose tegumentar americana: histórico, epidemiologia e perspectivas de controle. Rev Bras Epidemiol. 2004;7(3):328-37.

2. Shaw JJ, Ishikawa EAY, Lainson R. A rapid and sensitive method for the identification of Leishmania with monoclonal antibodies using fluoresce in-labeled avidin. Trans R Soc Trop Med Hyg. 1989;83(6):783-4.

3. Arias Ramirez J, Beltrán F, Desjeux P, Walton B. Epidemiología y control de la leishmaniasis en las Américas, por país o territorio. Washington: OPAS; 1996. (Cuaderno Técnico, 44).

4. Barbosa GMS, Marzochi MCA, Massard CL, Lima GPS, Confort EM. Aspectos epidemiológicos da leishmaniose tegumentar americana em cães, no município de Paraty, Estado do Rio de Janeiro, Brasil. Cad Saúde Pública. 1999;3:641-6. 
5. Galati EAB. Classificação de Phlebotominae. In: Rangel EF, Lainson R. Flebotomíneos do Brasil. Rio de Janeiro: Ed. Fiocruz; 2003. p. 23-51.

6. Lainson R, Shaw JJ, Silveira FT, de Souza AA, Braga RR, Ishikawa EAY. The dermal leishmaniases of Brazil, with special reference to the eco-epidemiology of the disease in Amazonia. Mem Inst Oswaldo Cruz. 1994;89(3):435-43.

7. Santos GPL, Sanavria A, Marzochi MCA, Santos EGOB, Silva VL, Pacheco RS, Mouta-Confort E, Espindola CB, Souza MB, Ponte CS, Conceição NF, Andrade MV. Prevalência da infecção canina em áreas endêmicas de leishmaniose tegumentar americana, do município de Paracambi, Estado do Rio de Janeiro, no período entre 1992 e 1993. Rev Soc Bras Med Trop. 2005;38(2):161-6.

8. Davies CR, Reithinger R, Campbell-Landrum D, Feliciangeli D, Borges R, Rodriguez N. The epidemiology and control of leishmaniasis in Andean countries. Cad Saúde Pública. 2000;16(4):925-50.

9. Lainson R, Shaw JJ. New World leishmaniasis. In: Cox FEG, Kreier JP, Wakelin D. Topley \& Wilson's microbiology and microbial infections, parasitology. London: Auckland; 2005. p. 313-49.

10. Dorval MEC, Oshiro ET, Cupollilo E, Castro ACC, Alves TP. Ocorrência de leishmaniose tegumentar americana no Estado de Mato Grosso do Sul, associada à infecção por Leishmania (Leishmania) amazonensis. Rev Soc Bras Med Trop. 2006;39(1):43-6.

11. Savani ESMM. Aspectos da transmissão de leishmanioses no Assentamento Guaicurus, Planalto da Bodoquena, Estado de Mato Grosso do Sul, Brasil, 2002-03. Infecção natural em animais domésticos e vetores [Master's thesis]. São Paulo: Universidade de São Paulo; 2004. 132 p.

12. Oliveira AG, Galati EA, Fernandes CE, Dorval ME, Brazil RP. Seasonal variation of Lutzomyia longipalpis (Lutz \& Neiva, 1912) (Diptera: Psychodidae: Phlebotominae) in endemic area of visceral leishmaniasis, Campo Grande, state of Mato Grosso do Sul, Brazil. Acta Trop. 2008;105(1):55-61.

13. Andrade ARO, Nunes VLB, Galati EAB, Santos MFC, Rocca MEG, Aquino RB. Fauna flebotomínea de Bonito, Estado de Mato Grosso do Sul, Brasil, 2006-2007. In: I Congresso do Centro Oeste de Doenças Infecciosas, Emergentes, Reemergentes e Negligenciadas/Diern. Campo Grande: Missão Saúde; 2007. 
14. Dorval MEMC, Cunha RV. Epidemiological studies in a cutaneous leishmaniasis area in the municipality of Bela Vista, Mato Grosso do Sul state, Brazil. J Venom Anim Toxins Incl Trop Dis. 2007;13(1):136.

15. Serra CMB, Leal CA, Figueiredo F, Schubach TM, Duarte R, Uchoa CMA, Silva RMM, Madeira MF. Leishmaniose tegumentar canina em Morada das Águias (serra da Tiririca), Maricá, Rio de Janeiro, Brasil. Cad Saúde Pública. 2003;19(6):1877-80.

16. Bonfante-Garrido R, Urdaneta I, Urdaneta R, Alvarado J. Natural infection of cats with Leishmania in Barquisimeto, Venezuela. Trans R Soc Trop Med Hyg. 1991;85(1):53.

17. Costa-Durão JF, Rebelo E, Peleteiro MC, Correia JJ, Simões G. Primeiro caso de leishmaniose em gato doméstico (Felis catus domesticus) detectado em Portugal (Concelho de Sesimbra): Nota preliminar. Rev Portug Cienc Vet. 1994;89:140-4.

18. Laruelle-Magalon C, Toga I. Un cas de leishmaniose féline. Prat Med Chir Anim Comp. 1996;31:255-61.

19. Passos VMA, Lasmar EB, Gontijo CMF, Fernandes O, Degrave W. Natural infection of a domestic cat (Felis domesticus) with Leishmania (Viannia) in the metropolitan region of Belo Horizonte, State of Minas Gerais, Brazil. Mem Inst Oswaldo Cruz. 1996;91(1):19-20.

20. Figueiredo FB, Pereira AS, Gremião IDF, Nascimento LD, Madeira MF, Schubach TMP. Leishmaniose tegumentar americana em felino doméstico no município do Rio de Janeiro: relato de caso. Clin Vet. 2008;74:58-60.

21. Schubach TMP, Figueiredo FB, Okamoto T, Barbiere I, Pereira AS, Cuzzi-Maya T, Andrade MV, Madeira MF, Leal CA, Silva RMM, Schubach AO. Leishmaniose tegumentar americana em gato doméstico (Felis catus) naturalmente infectado no Rio de Janeiro - Relato de isolamento de Leishmania sp. Rev Soc Bras Med Trop. 2003;36(1):342.

22. Souza AI, Barros EMS, Ishikawa E, Ilha IMN, Marin GRB, Nunes VLB. Feline leishmaniasis due to Leishmania (Leishmania) amazonensis in Mato Grosso do Sul State, Brazil. Vet Parasitol. 2005;128(1-2):41-5.

23. Pereira APC, Coutinho SDA. Criptococose em cães e gatos: revisão. Clin Vet. 2003;45:24-32.

24. Schubach TMP, Schubach AO. Esporotricose em cães e gatos: revisão. Clin Vet. 2000;29:21-4. 